\title{
Review Article \\ Potential Application of Green Composites for Cross Arm Component in Transmission Tower: A Brief Review
}

\author{
M. R. M. Asyraf $\mathbb{D},{ }^{1}$ M. R. Ishak $\mathbb{D},{ }^{1,2,3}$ S. M. Sapuan $\mathbb{D}^{3,4}$ N. Yidris $\mathbb{D}^{1},{ }^{1}$ R. A. Ilyas $\mathbb{D}^{5,6}$ \\ M. Rafidah, ${ }^{7}$ and M. R. Razman ${ }^{8}{ }^{8}$ \\ ${ }^{1}$ Department of Aerospace Engineering, Universiti Putra Malaysia, 43400 UPM Serdang, Selangor, Malaysia \\ ${ }^{2}$ Aerospace Malaysia Research Centre (AMRC), Universiti Putra Malaysia, 43400 UPM Serdang, Selangor, Malaysia \\ ${ }^{3}$ Laboratory of Biocomposite Technology, Institute of Tropical Forestry and Forest Products (INTROP), Universiti Putra Malaysia, \\ 43400 UPM Serdang, Selangor, Malaysia \\ ${ }^{4}$ Advanced Engineering Materials and Composites Research Centre (AEMC), Department of Mechanical and \\ Manufacturing Engineering, Universiti Putra Malaysia, 43400 UPM Serdang, Selangor, Malaysia \\ ${ }^{5}$ School of Chemical and Energy Engineering, Faculty of Engineering, Universiti Teknologi Malaysia, 81310 UTM Johor Bahru, \\ Johor, Malaysia \\ ${ }^{6}$ Centre for Advanced Composite Materials, Universiti Teknologi Malaysia (CACM), 81310 UTM Johor Bahru, Johor, Malaysia \\ ${ }^{7}$ Department of Civil Engineering, Universiti Putra Malaysia, 43400 UPM Serdang, Selangor, Malaysia \\ ${ }^{8}$ Research Centre for Sustainability Science and Governance (SGK), Institute for Environment and Development (LESTARI), \\ Universiti Kebangsaan Malaysia, 43600 UKM Bangi, Selangor, Malaysia
}

Correspondence should be addressed to M. R. M. Asyraf; asyrafriz96@gmail.com and M. R. Ishak; mohdridzwan@upm.edu.my

Received 29 September 2020; Revised 9 November 2020; Accepted 11 November 2020; Published 3 December 2020

Academic Editor: Yulin Deng

Copyright ( 2020 M. R. M. Asyraf et al. This is an open access article distributed under the Creative Commons Attribution License, which permits unrestricted use, distribution, and reproduction in any medium, provided the original work is properly cited.

\begin{abstract}
Recently, advanced technologies exploit materials from nonrenewable resources such as petroleum, natural gas, metal ores, and minerals. Since the depletion of these resources and environmental issues, it has brought attention to researchers to progress in the development of biodegradable materials from green composites. Most biofibres and biopolymers are obtained from agricultural waste products either from stem, leaf, stalk, or fruit. Nowadays, green composites with well-regulated life span have been widely discussed in numerous fields and applications. Some studies have shown that biofibres and biopolymers have comparable mechanical, thermal, and physical properties with glass fibre and other synthetic polymers. Thus, researchers are progressively narrowing down the development of green composite materials in many high strength applications, such as house deck and automotive components. This review focuses on the background of green composites (natural fibres and biopolymers), the manufacturing processes, potential applications in cross arm structures, and testing evaluations. This article also focuses on the specific current cross arm configurations and the pultrusion process to form squared hollow section beams. Many open issues and ideas for potential applications of green composites are analysed, and further emphases are given on the development of environmentally friendly material structures. Hence, the article is expected to deliver a state-of-art review on manufacturability and perspectives of natural fibre reinforced biopolymer composite cross arms for transmission towers.
\end{abstract}

\section{Introduction}

Currently, the growth of environmental concerns in manufacturing new materials among researchers and corporate sectors has increased; thus, the idea is to substitute the current material with more environmentally friendly fibres and resins $[1,2]$. Petroleum has been widely used for decades in order to power various transportation systems and also to produce many synthetic plastics such as polyester. However, they can last only for another 5-6 decades at the current rate of global consumption [3]. Another issue associated with petroleum consumption is the emission of greenhouse gases, such as methane and carbon dioxide, which contribute to global warming [4]. This issue has increased awareness of 
the finiteness of fossil energy resources, leading to the development of new materials that are entirely based on renewable resources. Mass production of petroleum plastics has also lead to a significant reduction of landfill capacities across the globe. This issue has led many nations to create new legislations and laws regarding plastic waste control, which educate the society to be more conscious on environmental issues. Subsequently, this phenomenon will drive many manufacturers and retailers to capitalise their finance on the development of green and sustainable products with acceptable costs to reduce the impact of global warming. Thus, the rising awareness among the public on the abundance of synthetic plastics as well as their effects towards the environment has brought an urgency to develop a technology based on biodegradable materials with acceptable properties [5].

In order to fabricate materials from used products, consumption of energy, raw materials, and cost would increase. Thus, several actions have been taken by scientists to find suitable alternative material sources. Renewable resources such as plants, animals, and minerals are the advantageous alternative sources on the condition of subsequent processing with low energy requirements [6]. A solution to the aforementioned statement is implementing naturally available fibrous resources from agricultural wastes. On top of that, plants could benefit the urban society in many ways, including as energy-saving structures in building structures and thermal insulation. In this case, there are several advantages of applying plant fibre in structural composite applications, such as thermal regulation of structures, protection from weather, and protection from direct sunlight. To ensure the advantages are grasped accordingly, it is necessary to consider suitability of the structures, types of plants, and locations in the plants, as well as questions of keeping the plants [7-10]. Thus, from the above statement, the plants' waste products not only can be harvested to become new materials but also can act as a sustainable and energysaving agent for urban building environment.

Previously, the aviation industry was the first forerunner of producing polymeric composite products [11]. This material has been implemented in various applications including the energy sector due to its ability in high mechanical strength and stiffness as well as lightweight property [1214]. These applications include the application of pultruded E-glass fibre reinforced unsaturated polyester cross arms in transmission towers [15] and wind turbines [16]. Specifically for cross arms, the pultruded glass fibre reinforced polymer (PGFRP) composite is the most suitable material next to Chengal wood due to its ability to arc-quench lightning strikes [17]. Moreover, the PGFRP cross arms are able to withstand constant loading of insulators and cables in long term [18, 19]. The synthetic polymeric composites have caused many major problems especially in recycling at the end of their life span. Moreover, the implementation of landfill disposal of used synthetic polymeric composites is not a suitable option due to the growth of environmental awareness among the society. This has pushed the government in implementing stricter regulations and law of landfill disposal [20]. In order to solve this issue, the application of alternatives for petroleum-based composites, such as renewable composite materials, has shown a significant effort to improve the current environmental quality [21, 22].

Green composites are the next generation of biocomposite material where natural fibre reinforced biodegradable polymer forms a lightweight and strong structure material $[2,23]$. Hence, this review article focuses on the potential of natural fibre reinforced biopolymer composites (NFRBCs) in a cross arm structure for transmission tower application. NFRBCs or green composites could potentially replace the current synthetic composite in cross arm application due to their properties including high mechanical strength and excellent biocompatibility, and they have gained more attention and a growing field in material technology. A general review on green composites composed of plant fibre and bioplastic was done by several researchers [23-26]. Although there is a numerous amount of literature available on biobased composite materials, there is lack of extensive review articles that specifically focus on manufacturability and application of green composites for cross arm beam application. This work highlights on the current research that has been carried out in the field of green composites. Further elaborations on the natural fibre, biopolymer, manufacturing process of green composites, and its potential applications on cross arm structures will be discussed in the subsequent subtopics.

\section{Green Composites}

Composite materials are divided into several classifications, such as (1) fibre reinforced composites, (2) particle reinforced composites, and (3) structural composites [20]. Green composites are one of the subsets of composite materials composed of both fibre and polymer originating from nature or recycled resources [27]. These materials include plant fibres, such as flax, kenaf, sugar palm fibres, recycled wood, or even waste paper-based fibres [28-31]. In order to select the most appropriate biofibre and biopolymer in a composite, several factors are essential to be fulfilled including tensile stiffness and strength, fibre treatments, thermal stability, elongation at failure, and fatigue and creep resistance properties [3235]. For green composite products, they can be fabricated through various processes which employ the analysis and optimization methods in composite technology. The processes include mixing, wetting, and saturating the fibre and resin together in order to achieve better bonding of firm composite structure. This would later contribute to better mechanical performance, thermal stability, and heat reaction $[21,28]$.

The current applications of natural fibre reinforced biopolymer composites are emerging in many sectors. Table 1 shows the progresses of green composites in many sectors including transportation, construction, sports, electronics, household, and material handling and storage $[24,36]$. In addition, the rising demands for the advanced materials with tailored physical and mechanical properties have made the natural fibres as the most attractive composite materials for high-performance applications.

2.1. Natural Fibre: Plant Cellulosic Fibre. Rapid depletion of fossil fuel resources alongside the growth of environmental 
TABLE 1: Common applications of natural fibre reinforced composites in various industrial sectors [100-108].

\begin{tabular}{|c|c|}
\hline Sector & Application \\
\hline Electronics & Laptop cases and mobile \\
\hline Sports & Ball, snowboard, bicycle frame, fork, seat post, and boats \\
\hline Transportation & $\begin{array}{l}\text { Door panel, engine rubber insulation, engine cover, floor mat, dashboard, car spoiler, hand-brake, } \\
\text { steering, pedal components, parcel shelves, interior carpet, and body panels }\end{array}$ \\
\hline Building and construction & Bridge, railing, false ceiling, partition boards, windows, door frames, mobile structures, wall, and floor \\
\hline Household & $\begin{array}{l}\text { Mug pad, chairs, coffee table, shoe rack, suitcases, food tray, partitions, safety helmet, ropes, } \\
\text { fencing elements, showers, bath units, and pipes }\end{array}$ \\
\hline Materials handling and storage & Post-boxes, biogas containers, fuel container, and storage silos \\
\hline
\end{tabular}

awareness due to excessive production of man-made fibres is the main drive to substitute them with natural fibres as green composites. The natural fibres have attracted the researchers and industries, since it is sustainable in nature. These fibres are categorized based on their origins, such as plants, geological processes (mineral), and animals [37, 38]. Among these natural fibre origins, the plants are most widely implemented as reinforcement in composite materials. Figure 1 displays the classifications of natural fibres.

Nowadays, plant-based fibres have progressively replaced synthetic fibres as reinforcement agents in composite materials for various industrial applications and household products. This is due to researchers' and manufacturers' interests with the ecological advantages and low capital cost during manufacturing process [39-41]. These fibres have extra advantages over synthetic fibres, such as cheap, high strength, ease of handling, low fossil-fuel energy requirements, and can deliver high mechanical properties. A report from Karus [42] discussed on $4.3 \times 10^{6} \mathrm{~kg}$ of cellulosic fibre being utilized by the automobile industries every year as reinforcing agents in composites. For plant fibre, they are divided into several types depending on where they are extracted. Figure 2 displays various subdivisions of plant cellulosic fibres [30].

The increasing usage of plant-based fibres can be attributed to their affordability, availability, biodegradability, renewability, recyclability, and processability [43-45]. Additionally, plant fibres can also benefit the composite industry in many ways, such as permit better tensile strength and stiffness, good insulation performance, lightweight, consume less energy during fabrication, and less health risk especially respiratory diseases $[46,47]$. Based on the aforementioned statements, most plant-based fibres demonstrate that they are the prominent candidates to substitute man-made (synthetic) fibres in most sectors in the composite industry. Table 2 shows the comparison between plant-based fibres and man-made fibres.

All mentioned plant fibres are termed as nonwood fibres. Currently, many developers and scientists have narrowed the implementation of nonwood fibres to assist the effort of preventing deforestation. In this case, the depletion of wood timber in wood-plastic composites for construction has caused a massive destruction of biodiversity. For example, Malaysia has reported that around $14.4 \%$ of its tropical forests have been lost from 2000 to 2012, in which the land area covers about $47,278 \mathrm{~km}^{2}$ [48]. Thus, the application of nonwood fibre seems to be a solution for this issue to substitute synthetic fibres. These nonwood natural fibres have good comparable values with synthetic fibres such as glass fibres. Table 3 depicts the comparison of tensile properties of glass fibres and other well-known natural fibres.

However, the main problem associated with plant fibregreen composites is low thermal stability in order to be applied for engineering applications. Hence, it is essential to improve the thermal stability of plant fibres using modifications to produce better performance of green composites to be used in wider applications. According to Ramesh [49], the dynamic mechanical properties and thermal stability are dependent on the fibre weight fraction of the composites. Meanwhile, the modified plant fibre-based green composites that show losses of modulus peaks are widened due to improved fibre/matrix adhesion [50]. In another study conducted by Belhassan et al. [51], thermal behaviour of the improved green composites was comparable with the synthetic fibre composites. This can be proven based on their morphological analysis which depicted that the interaction between untreated plant fibres with their matrices was poor due to the occurrence of fibre debonding, fibre pull-out, matrix fracture, and fibre fracture.

2.2. Biopolymer. Polymer is a chemical substance made up from a number of repetitive subunits. According to Ramesh [52], the exploitation of biopolymer is the most prominent aspect compared to plant fibre to ensure environmental sustainability. Since they have a wide range of behaviours, both synthetic and natural polymers are vital materials in many sectors from the industrial scale to household products [53]. In general, plastics are composed of a long chain of polymers formed by the addition of polymerization reactions and condensation processes $[54,55]$. From these processes, they can be formed either in thermosetting or thermoplastic polymers. These polymers are obtained from petroleumbased (synthetic polymer) and renewable-based (biopolymer) resources. Bio-based plastics are made up from renewable and natural resources such as plant oils, latex, starch, and animal fats. On the other hand, biodegradable plastic means that it can be decayed by action of living organisms (fungi and bacteria) into water, carbon dioxide, and biomass. Figure 3 shows the demonstration of conventional and bio-based polymer. 


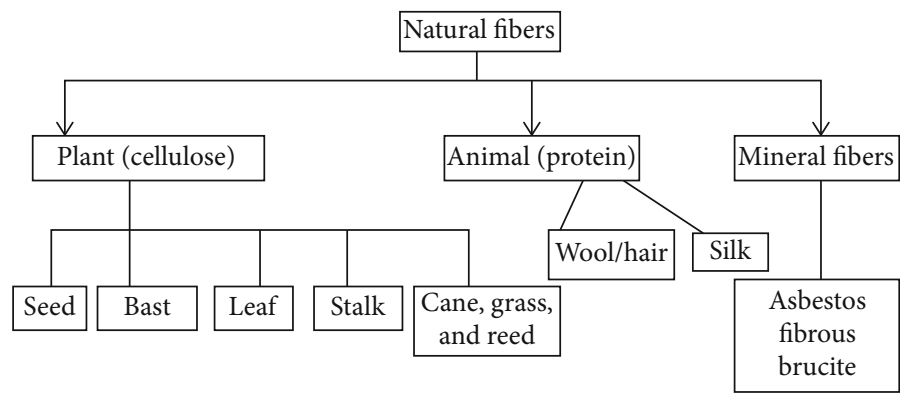

FIGURE 1: Classifications of natural fibres.

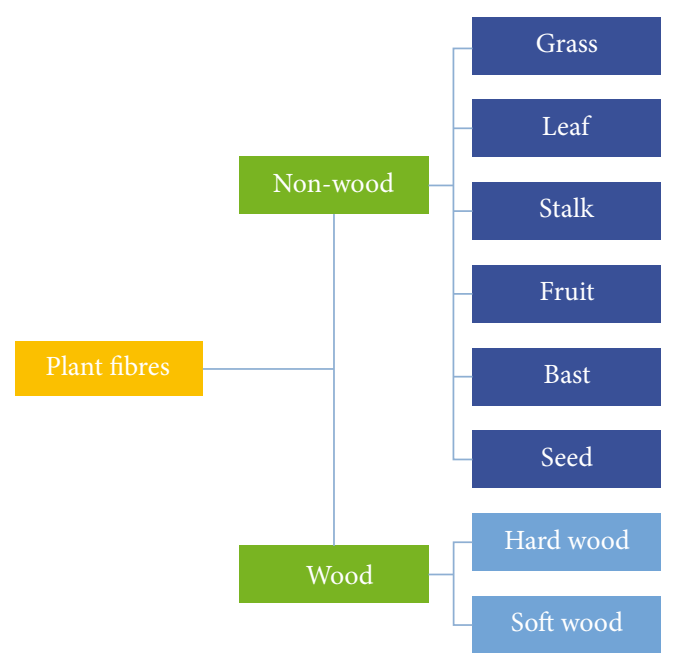

FIgURE 2: Classification of plant cellulosic fibres.

Typically, polymer has a significant ability to resist chemical reaction as well as both electric and thermal insulators. They are also lightweight which also possess good mechanical properties in terms of stiffness and strength. Table 4 shows the list of mechanical and physical properties of biopolymers and synthetic polymers. On top of that, they can be manufactured in various ways either in open or closed moulding techniques. They have a limitless range of characteristics and colours, and they can be used to produce items that have no alternatives from other materials [56].

\section{Manufacturing of Green Composites}

In common practices, green composites from both polymer and fibre can be fabricated from various manufacturing processes either in open or closed moulding systems. Open moulding fabrication process involves hand layup, spray layup, and filament winding. This process exposes both resin and fibre to air as they cure or harden [57]. Open moulding is usually applied to a composite product, which is large, and has a complex shape, whereby the design option is virtually limitless. However, the problem of this fabrication technique is that it has low volumes, which contribute to higher moulding costs of automated processes. Apart from open moulding system, closed moulding is another common manufacturing process of composite products applied in enclosed and heated cavity for curing using pressure pump or vacuum
[58]. The examples of closed moulding techniques are compression moulding, resin transfer moulding, pultrusion, injection moulding, hot pressing, and vacuum infusion moulding [59]. These manufacturing techniques enable product developers to produce better parts faster and consistent with lesser waste. At the end of the process, the end products have good surface finishes, which eliminate postwork activities. Nevertheless, manufacturers have to bear the initial capital cost of tools and equipment. Figure 4 depicts the classifications of fabrication processes of green composite products.

There are several criteria needed to be fulfilled using these conventional manufacturing processes as these are primarily designed from synthetic composites. Thus, pretreatment process, either chemically or physically, is required for natural fibres to improve interfacial adhesion with their matrix in composite laminates [60,61]. Pretreatment of fibres improves fibre-matrix interfacial interactions, improving processability and properties of green composites. Specifically for cross arm beam fabrication process, pultrusion process is implemented as the product is in symmetrical square shape in the long beam section. The following subtopic elaborates on the specific process of pultrusion of composite products.

3.1. Current Fabrication Method: Pultrusion. Pultrusion is a fabrication process of composite profile by impregnating the fibre with thermosetting matrix and is pulled via heated die [62]. In general, this fabrication technique has the capability to operate continuously in order to produce symmetrical section profile such as cross arm (Figure 5) with high volume rate.

In the pultrusion process, it can be categorized into three main zones, which are pulling zone, heat transfer zone, and pressure zone [63]. Initially, a thermosetting resin bath with appropriate viscosity is ready to impregnate the fibre from the creel by pulling them towards the basin as shown in Figure 6. Guide plates are applied in the system to direct the fibre inside the resin bath for impregnation process. The resin bath contains thermoset resins along with its filler, colouring pigment, catalyst, release agent, stabilizers, and ultraviolet ray to initiate the curing process of impregnated resin. After that, the fibres are pulled out via preform guides to remove excess resin before going inside heated die for curing. This heated die is also called the curing zone. Within the heated die, it is divided into two zones, which are low 
TABLE 2: Comparison of natural fibres to man-made fibres [109].

\begin{tabular}{lcc}
\hline Attributes & Natural fibre & Man-made fibre \\
\hline Raw material cost & Low & High \\
Manufacturing cost & Low & High \\
Weight/density & Light & Heavy \\
Disposal & Highly degradable & Takes thousand years to be composed \\
Availability & Widely available & Depleted from time by time \\
Renewability & Yes & No \\
Recyclability & Yes & No \\
Energy usage & Low & High \\
Health risk & No & Yes \\
\hline
\end{tabular}

TABle 3: Comparison between glass fibres with various plant fibres [90, 110-118].

\begin{tabular}{lccc}
\hline Fibre & Tensile strength (MPa) & Elongation at break & Tensile modulus (GPa) \\
\hline Banana & 355.0 & 5.3 & 33.8 \\
Jute & $400.0-800.0$ & 1.8 & $10.0-30.0$ \\
Bagasse & $20.0-290.0$ & 1.1 & $19.7-27.1$ \\
Coir & 220.0 & $15.0-25.0$ & 6.0 \\
Abaca & 980.0 & - & - \\
Cotton & 400.0 & $3.0-10.0$ & 12.0 \\
Flax & $800.0-1500.0$ & $1.2-1.6$ & $60.0-80.0$ \\
Kenaf (bast) & 295.0 & $2.7-6.9$ & - \\
Sisal & $60.0-700.0$ & $2.0-3.0$ & 38.0 \\
Hemp & $550.0-900.0$ & 1.6 & 70.0 \\
Pineapple & $170.0-1627.0$ & $1.0-3.0$ & 82.0 \\
Sugar palm & 42.1 & 9.8 & 10.4 \\
Ramie & 500.0 & 2.0 & 44.0 \\
Oil palm (empty fruit bunch) & 248.0 & 2.5 & 3.2 \\
Henequen & $3.0-4.7$ & - & - \\
S-glass & 4570.0 & 2.8 & 86.0 \\
E-glass & 4570.0 & 2.8 & 86.0 \\
\hline
\end{tabular}

temperature for gelation and high temperature for curing action. In this part of the pultrusion, the die is heated by the heater that embeds thermocouple sensor to ensure the temperature is sufficient enough for curing. Moreover, the thermocouple sensor also functions to avoid the die from overheating which could flaw the composite profile.

Typically, the pultrusion of composite profiles apply continuous unidirectional fibres impregnated with low viscosity thermosetting resin [62]. Later, the resin would be in rubbery state from liquid state. This transition point is called as gelation point, which later solidifies to form solid pultruded profile $[64,65]$. Overall, the movement of pultrusion line is controlled by pneumatic controller system that instructs the hydraulic clamp to pull the profiles through cutter as displayed in Figure 6. Moreover, the hydraulic clamp is installed with rubber to grip and protect the composite profiles. The pulling speed is controlled using a programming control system, and it can be easily monitored and controlled in the monitor screen.
3.2. Other Potential Advance Fabrication Method: Filament Wounding. Filament winding is another advanced manufacturing method which implements impregnated fibre with polymer resin thoroughly onto the rotating mandrel. The winding angle, patterns, and rotation number are automatically controlled by a computerised system. In terms of application to transmission lines, this method could produce better beams for cross arm members in latticed tower [66, 67].

In general, there are three types of winding patterns in this manufacturing process, which are hoop, helical, and polar windings as shown in Figure 7 [29]. Morozov [68] found out that mechanical properties of thin-walled filament wind structure depend on its winding patterns. The stress and strain distributions are affected by the size of the triangular mosaic units and their numbers per unit of length in both longitudinal (hoop) and circumferential (helical) directions. Thus, it is suggested that the cross arm beams to be fabricated, to implement hoop and helical windings to ensure 


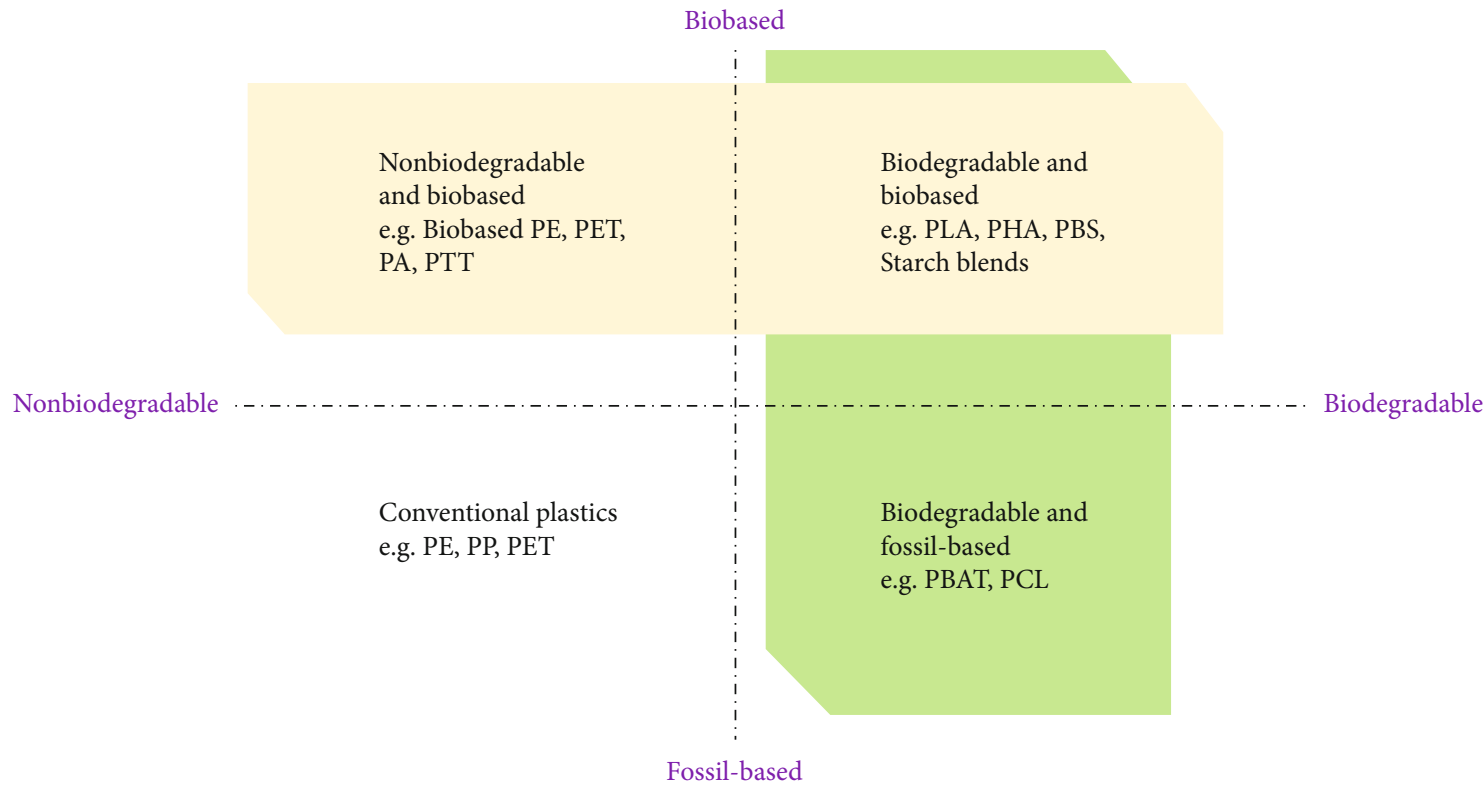

Figure 3: Classification of polymers.

TABLE 4: Comparison of man-made petroleum-based polymers with biopolymers [119-122].

\begin{tabular}{lccc}
\hline Polymers & $\begin{array}{c}\text { Tensile } \\
\text { strength } \\
(\mathrm{MPa})\end{array}$ & $\begin{array}{c}\text { Elongation } \\
\text { at break (\%) }\end{array}$ & $\begin{array}{c}\text { Tensile } \\
\text { modulus } \\
(\mathrm{GPa})\end{array}$ \\
\hline $\begin{array}{l}\text { Petroleum-based polymer } \\
\text { Polyester }\end{array}$ & $41.4-89.7$ & 2.6 & $2.06-4.11$ \\
$\begin{array}{l}\text { Low-density } \\
\text { polyethylene (LDPE) }\end{array}$ & 190.0 & 190.0 & 0.21 \\
$\begin{array}{l}\text { High-density } \\
\text { polyethylene (HDPE) }\end{array}$ & 20.3 & 380.0 & 0.91 \\
$\begin{array}{l}\text { Poly(ethylene } \\
\text { tetraphthalate) (PET) }\end{array}$ & 55.0 & 130.0 & 2.70 \\
$\begin{array}{l}\text { Epoxy } \\
\text { Biopolymer }\end{array}$ & 26.0 & 2.33 & 1.21 \\
$\begin{array}{l}\text { Poly(lactic acid) (PLA) } \\
\text { Poly(hydroxyalkanoate)s } \\
\text { (PHA)s }\end{array}$ & 49.6 & 2.4 & 3.60 \\
$\begin{array}{l}\text { Poly (3-hydroxybutyrate) } \\
\text { (PHB) }\end{array}$ & 36.4 & 2.1 & 2.99 \\
$\begin{array}{l}\text { B-lactorglobulin }+ \\
\text { glycerol }\end{array}$ & 4.9 & 11.4 & 0.15 \\
\hline
\end{tabular}

well-distribution of stress from dead weights of electric cables and insulators as well as dynamic loading from winds.

Another advantage of implementing filament winding for cross arm beam fabrication is they can manufacture these beams with their core structures simultaneously. This manufacturing technique allows the beams to have more coherent thickness distribution along with their core structures. Further elaboration on reinforcement of core structure of cross arm will further be discussed in the next subsection.
3.3. Potential Reinforcement of Core Structure in Cross Arm Beam to Enhance Its Strength. Core structure can be defined as a thin-walled composite structure that contains aluminium, NOMEX, and natural fibre composites (NFCs) cores which join them by using either adhesive or brazing. Figure 8 displays the laminated wood timber which acts as a core structure inside pultruded glass fibre reinforced polymer composite (PGFRPC) square hollow section. There are various types of cores used to reinforced beams such as balsa wood, honeycomb, NOMEX, foam, and corrugated and tetrahedral truss core. The facing of the thin-walled structure is usually thinner than the core to ensure the produced material is stiff and strong $[69,70]$. In common practices, the composite filled core structures have various functions and applications depending on durability, manufacturing and raw material costs, and availability. For instance, graphiteepoxy and carbon-epoxy are the facings that enclose the NOMEX or aluminium honeycomb core for aerospace structures in order to resist extreme environment conditions [71]. Meanwhile, in marine and civil structure sectors, the typical facings implemented are glass-epoxy or glass-vinyl ester reinforced with close-cell or open-cell foam [72, 73]. Balsa with various densities has typically become a choice for sandwich structure's core in ship application [69].

From the aforementioned statement, honeycomb core structure is one of the potential improvements associated to have high durability and longer service for cross arm structure. This could be due to honeycomb core to be lightweight as well as has high bending strength and stiffness $[74,75]$. The innovation of honeycomb sandwich structure has been paid generous attention, and this has led to the development of filled-type, embedded, tandem, and hierarchical $[76,77]$ as displayed in Figure 9. From the previous studies $[78,79]$, it can be seen that the filled sandwich structure has currently attracted researchers because of its simple configuration and ease of manufacturing. In order to optimize the 


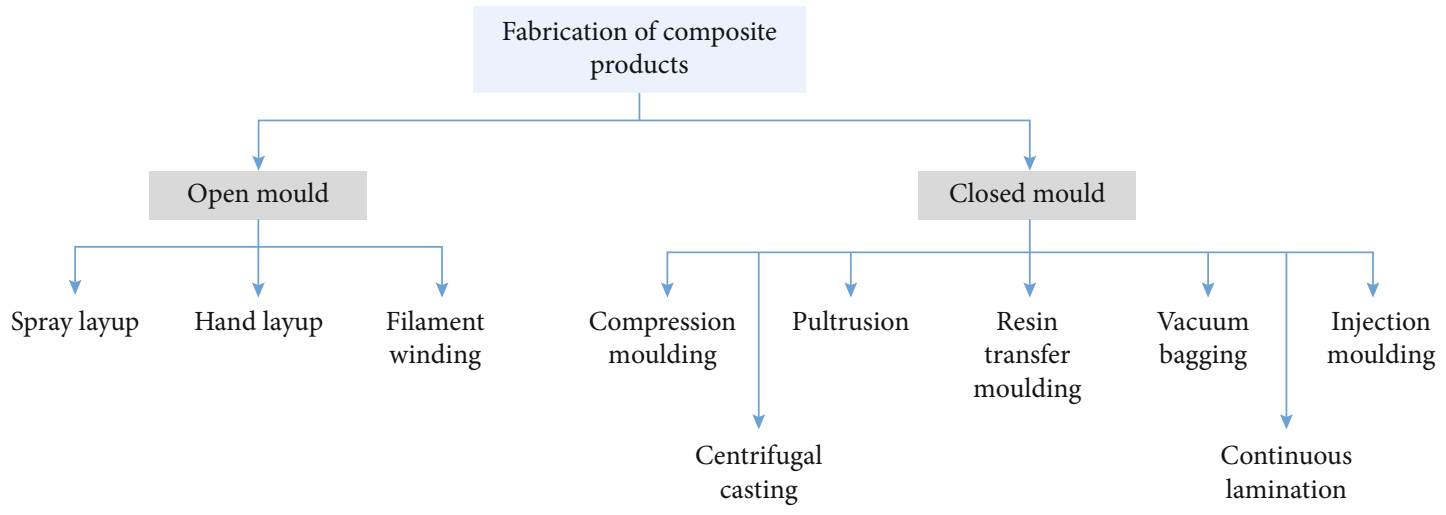

Figure 4: General classification of green composites fabrication processes.

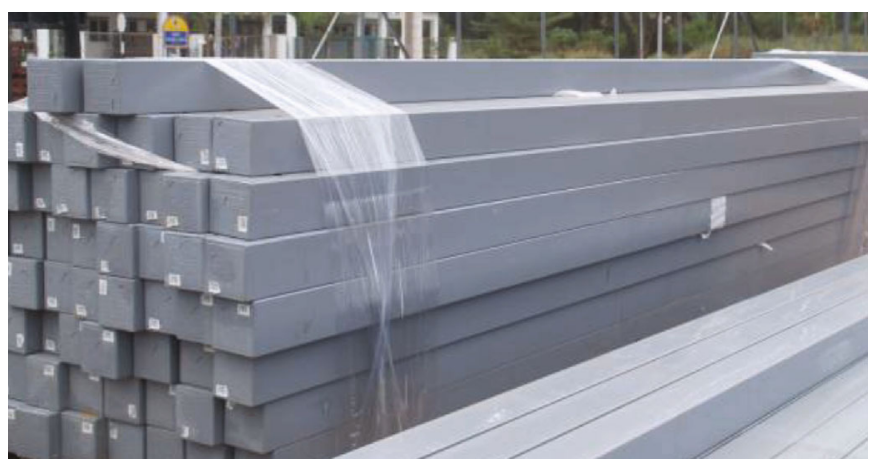

Figure 5: Cross arm beams in stockpiles after pultrusion for distribution.

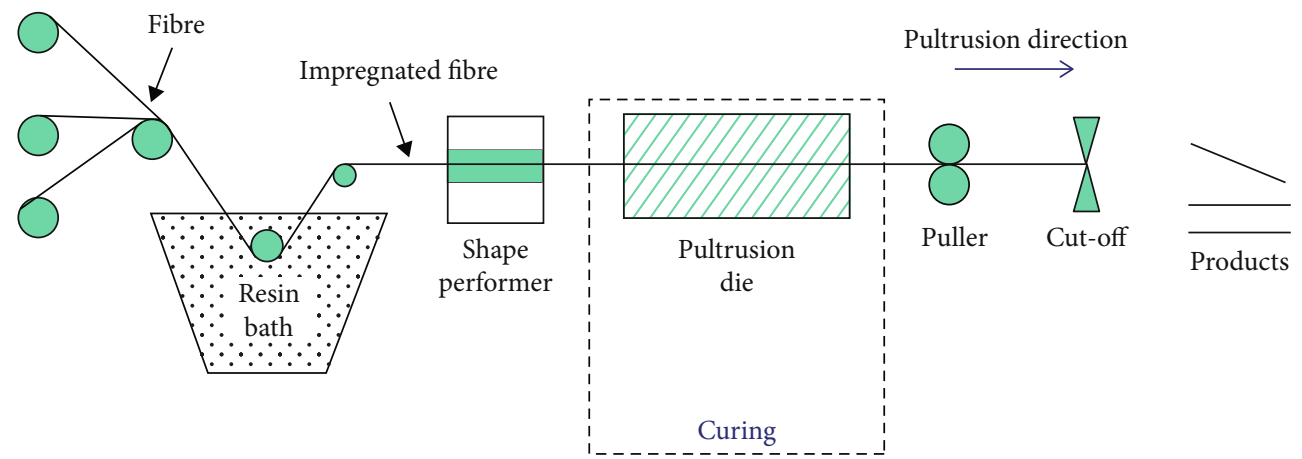

FIGURE 6: Schematic diagram of pultrusion process of pultruded composite.

composite filled core structure, various fillers have been investigated to seek the optimal combination including foam, honeycomb, lattice-filled, and balsa wood [80-82]. Another way to fabricate composite filled structure is by embedding the honeycomb cell with foam, tubes, or even other polymer materials using the concept of a container instead of a filler [83]. For tandem honeycomb structure, it is considered to combine several segments with a separator between each segment. The idea of a separator is using it to distinguish segments from each other and to deliver interactions between them [84].

\section{PGFRP Composite: Current Cross Arm's Material}

Based on previous literature, the current cross arm in transmission tower used pultruded glass fibre reinforced polymer (PGFRP) composites [85, 86]. Previously, Chengal wood cross arm was applied to the transmission tower since 1963 due to its ability to arc quench lightning strikes and has better mechanical performance $[87,88]$. However, the wooden cross arm seemed to degrade and started to fail due to natural wood defect and attack from termites and microbes [89]. 


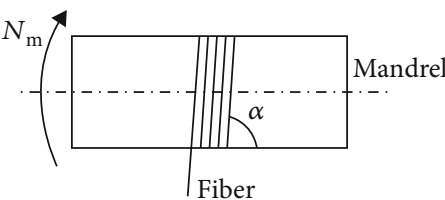

(a)

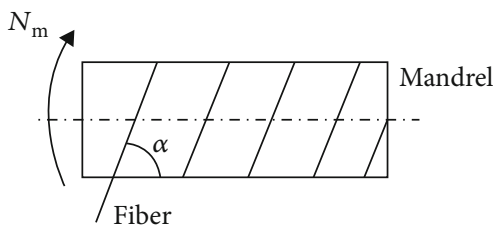

(b)

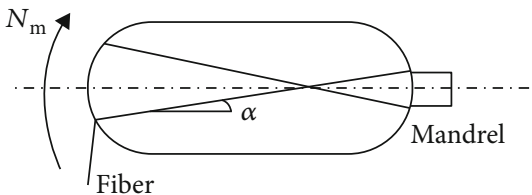

(c)

Figure 7: Types of winding patterns: (a) hoop, (b) helical, and (c) polar windings [29].

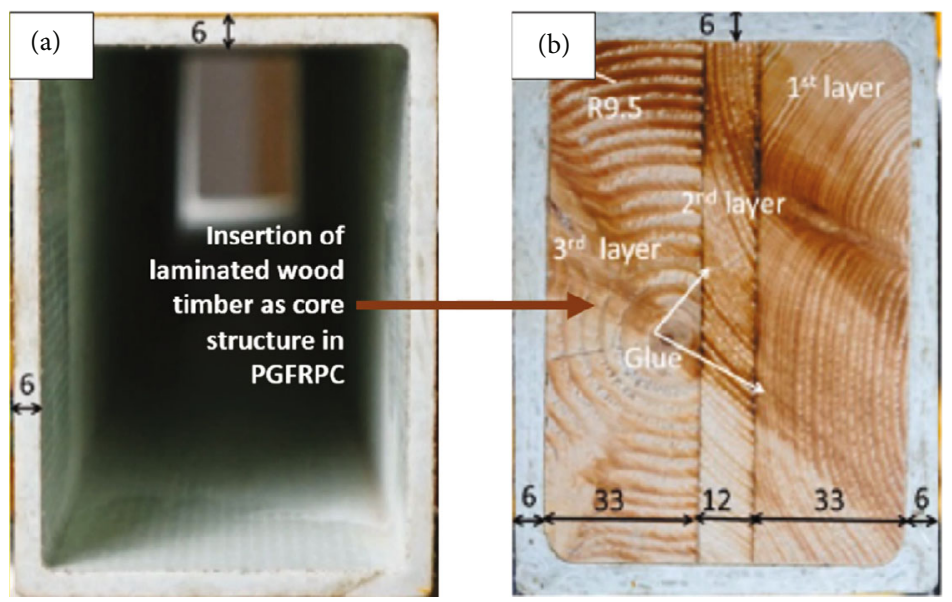

FIGURE 8: Sandwich composite structure layout.

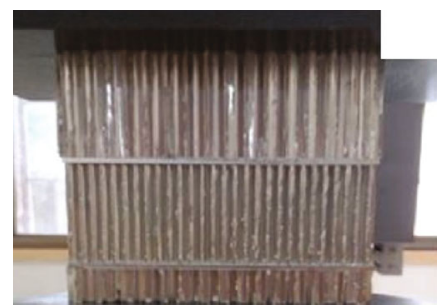

(a)

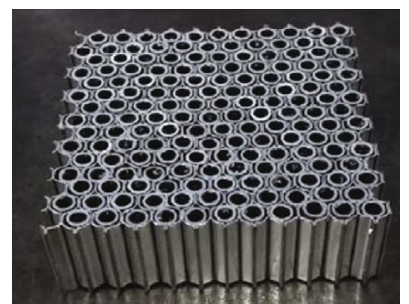

(b)

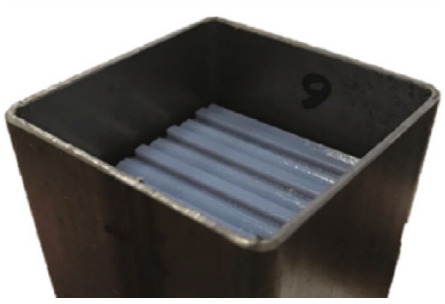

(c)

Figure 9: Innovation of honeycomb structures. (a) Tandem honeycomb structure. (b) Embedded honeycomb structure. (c) Honeycombfilled structure.

This has led researchers and engineers to conduct a research to shift wooden cross arms to PGFRP cross arms.

In general, the PGFRP composites have become the successor for wooden cross arms due to good tensile strength and stiffness, lightweight property, better bending strength and stiffness, as well as good electrical and thermal insulation properties [90, 91]. The PGFRP composite is made up of Eglass fibre reinforced with unsaturated polyester (UPE) resin with ratio of $37: 63$ in order to achieve optimum mechanical performance [92]. The PGFRP composite also seems to be lightweight as both densities of E-glass fibre and unsaturated polyester are less, of around 2580 and $1350 \mathrm{~kg} / \mathrm{m}^{3}$, 
TABle 5: Comparison between PGFRP composites and structural steel used in cross arms system [86].

\begin{tabular}{lcc}
\hline Properties & $\begin{array}{c}\text { PGFRP } \\
\text { composite }\end{array}$ & $\begin{array}{c}\text { Structural } \\
\text { steel }\end{array}$ \\
\hline $\begin{array}{l}\text { Density }\left(\mathrm{kg} / \mathrm{m}^{3}\right) \\
\text { Poisson ratio, } v_{x y}=v_{y z}=v_{x z}\end{array}$ & 1800 & 7850 \\
Shear modulus, $v_{x y}=v_{y z}=v_{x z}$ & 0.28 & 0.3 \\
$(\mathrm{MPa})$ & 4000 & 76923 \\
Young modulus in $x, E_{x}(\mathrm{MPa})$ & 16000 & 200000 \\
Young modulus in $y, E_{y}(\mathrm{MPa})$ & 4800 & 200000 \\
Young modulus in $z, E_{z}(\mathrm{MPa})$ & 1440 & 200000 \\
\hline
\end{tabular}

respectively. The overall mechanical and physical properties of PGFRP composite and structural steel are demonstrated in Table 5.

In terms of surface finish, the PGFRP composite has homogenous, fine, and unidirectional fibre along its polymer laminate. The optimal configurations for PGFRP composite, specifically for cross arm beams, five layers of E-glass fibre are laminated with various orientations and thicknesses in order to attain high mechanical and structural properties [86]. Table 6 elaborates the fabric orientations and its thickness layers to form pultruded square profile of cross arm beams.

\section{Potential Applications of Green Composites in Cross Arm Structures}

Natural fibre reinforced biopolymer composites are vital potential prospects of green technologies based on numerous findings emphasized in this review. One of these interesting inventions of the green composites is the simplicity of processing with various types of biopolymers. Other than that, the highlighted findings in this review also found that green composites have great potential as alternative composite materials for cross arm beams (Figure 10) due to their lightweight property and low cost. Other cross arm application in transmission tower is as bracing arm as shown in Figure 11. Currently, the ongoing research used wooden bracing arms to reinforce cross arm structure for better structural and long-term mechanical performances [93]. Thus, it is highly suggested to apply pultruded green composites as a replacement candidate for both cross arm beams and bracing arms.

Based on the previous paragraph, the green composites have high potential to substitute the PGFRP cross arms (Figure 10) and wooden bracing arms (Figure 11) as new materials in transmission tower applications. However, comprehensive studies have to be carried out for fabricated green composite cross arms with additional members in terms of mechanical and electrical insulation performances. The test evaluations include mechanical quasistatic test, creep test, and electrical resistance test before the newly fabricated green composite cross arms compute their services in electrical suspension towers.
TABLE 6: Fabric orientation and fibre thickness of PGFRP composite [86].

\begin{tabular}{lcc}
\hline PGFRP composite layer & Fabric orientation $\left({ }^{\circ}\right)$ & Thickness $(\mathrm{mm})$ \\
\hline Fifth (Inner) & 45 & 0.7 \\
Forth & 0 & 3.6 \\
Third & 90 & 0.7 \\
Second & -45 & 0.5 \\
First (Outer) & 45 & 0.5 \\
\hline
\end{tabular}

\section{Test Evaluation}

6.1. Creep Test. To extend the description of the loading mechanisms at prolonged time of pultruded green composite cross arms in such applications, many research works have emphasized on creep experiments in both coupon-scale and full-scale cross arms [33]. This creep test is conducted to investigate the strength of the structure and material, failure mode, elasticity, and viscoelasticity under constant load in long-term period $[12,32]$. The creep strain, creep compliance, stress-independent material constant, creep failure, and creep life are the interesting topics, especially for cross arm structures. Thus, related previous studies from creep responses of cross arm structures are highlighted to give a clear picture for any potential evaluation before being commercialised in the energy sector.

Currently, recent research works have been conducted especially in providing testing facilities to evaluate longterm mechanical performances of cross arms. According to Asyraf et al. $[94,95]$, two conceptual designs of creep test rigs, specifically for cross arm structures, have been developed in order to set up a platform for creep testing in three-point flexural and cantilever beam tests. This research team has designed both test rigs using hybridization of TRIZ, Morphological chart, and Analytic Network Process to generate ideas, refine attributes and characteristics, as well as design selection. Along these processes, both computeraided drawing (CAD) and finite element analysis (FEA) tools were used to compute the process systematically and optimize the designs based on actual scenarios based on the structural principles [96].

Other than that, many creep studies and long-term mechanical performance comparisons of cross arm's coupons have been conducted. For instance, Johari et al. [18] have evaluated the influence of calcium carbonate $\left(\mathrm{CaCO}_{3}\right)$ on creep response of PGFRP composite cross arms. In the research, the conventional creep and time-temperature superposition (TTSP) methods were evaluated, and it was found that the $\mathrm{CaCO}_{3}$ did not influence the long-term performance of the pultruded laminates. Moreover, both pultruded composites (with and without $\mathrm{CaCO}_{3}$ ) had the same creep life of about 25 years.

All in all, it is noteworthy that the evaluation of creep performances and responses in both conventional and accelerated creep techniques are highly important for new green composite cross arm structures. Moreover, before coming to the experimental stage, the test facilities have to be 


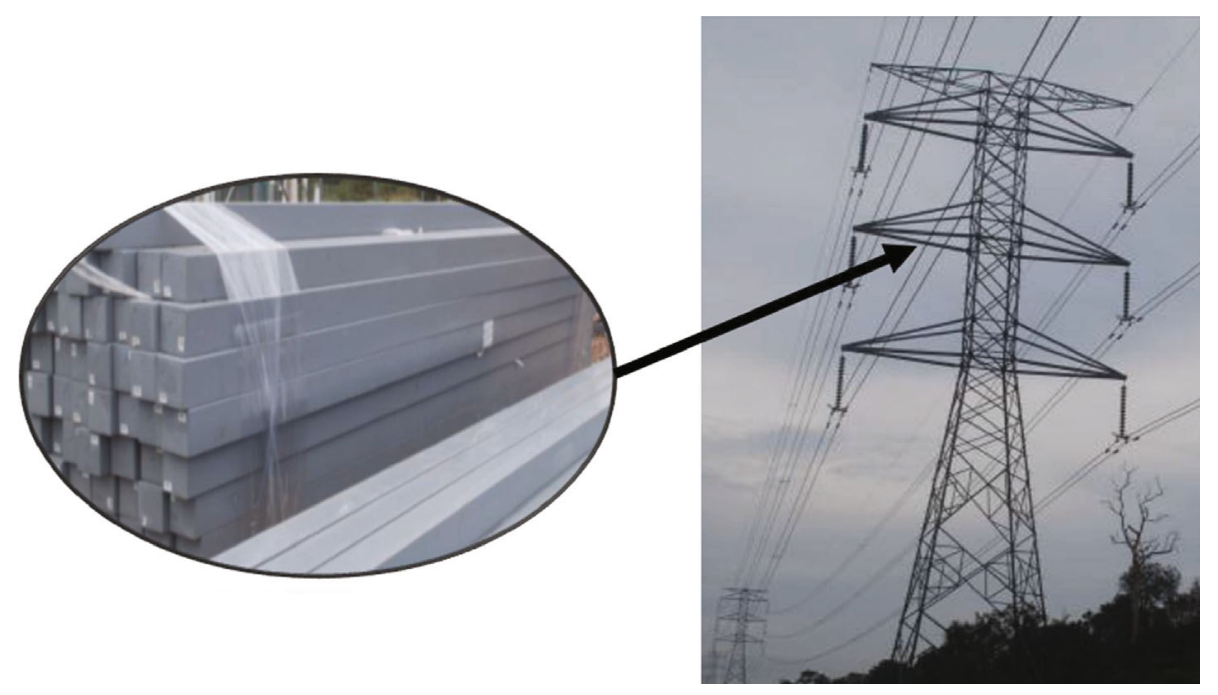

Figure 10: Potential application of green composite in cross arm beams.

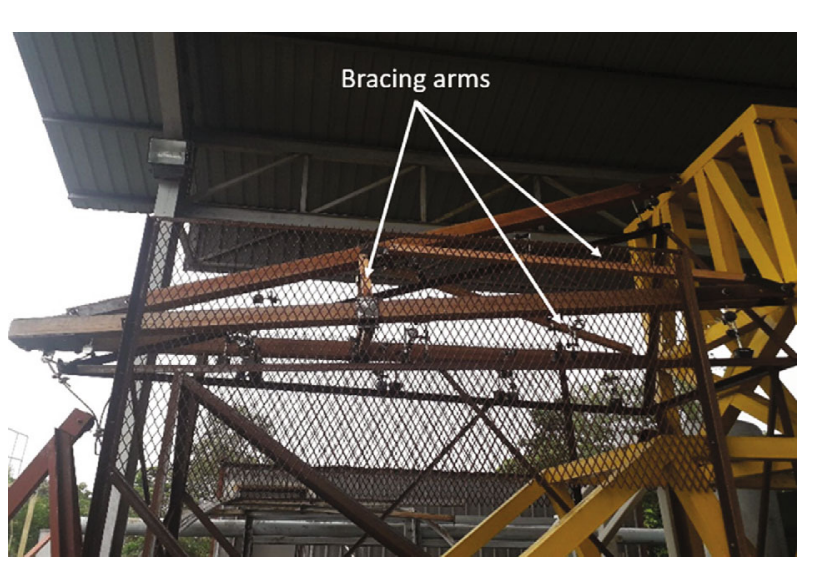

FIGURE 11: Potential application of green composite in bracing arms.

designed and developed to execute the specialised tests and analyses for structural evaluations.

6.2. Quasistatic Mechanical Test. In the past 20 years, many research activities have been executed to address the mechanical strength and performances of PGFRP composite beams. Since PGFRP cross arms are made up of pultrusion and in square hollow shape, it helps the structures to be low selfweight and has corrosion resistance capability. However, the cross-section geometry in the cross arm beams has caused a very complex behaviour as it is subjected to multiaxis compression forces. This phenomenon may induce a concentric compression due to immediate loading action, which subsequently causes a buckling reaction. Hence, a series of quasistatic mechanical tests and analyses is required to ensure the fabricated green composite cross arms fulfil the mechanical property standards as their predecessors (wood and PGFRP composites).

An earlier study conducted by Cardoso et al. [13] developed a comprehensive mathematical formulation to govern the mechanical strength of PGFRP square hollow composite under buckling action. From this research, PGFRP composites with longer length and lower strength specimen were exposed to higher potential of failure during postbuckling stage. Postbuckling was observed on the behaviour and interaction between crushing and local and global buckling.

In another study, Sharaf et al. [93] have also designed and examined full-scale wooden cross arms using quasistatic mechanical tests in both normal and broken wire conditions. The findings proved that the design of wooden cross arms experienced deflection and were exposed in broken wire condition, which was higher than normal wire condition. Afterwards, Sharaf et al. [97] developed a conceptual design of cross arm structure with the incorporation of bracing arms. A simple computational simulation using finite element analysis was executed to identify the best design with the most optimal mechanical and structural performances.

Thus, the previous literature shows that it is necessary to evaluate quasistatic mechanical properties of green composite cross arms and to guarantee the newly fabricated cross arms to be at least at par with PGFRP composite.

6.3. Electrical Capacity Test. From the view of electrical capacity of cross arms, it is essential for any cross arms to have their voltage stress, relative permittivity, volume conductivity, and current density examined. This is required in order to ensure continuous electrical supply to end users for urban and rural areas [98, 99]. These aspects are vital for cross arm structures to avoid experiencing any structural failures which could cause disruptions along the transmission line [91]. Some failures that cross arms might experience are being burnt by the electrical tracking and forming a charred path, creating some cavities which reveal the PGFRP composite structure as shown in Figure 12. From an analysis conducted by Rawi et al. [17], the cross arm located at the top of transmission tower experienced the highest peak voltage during lightning that stroke the earth wire of the cross arms. This was due to distance from the stricken point to the cross arms. 


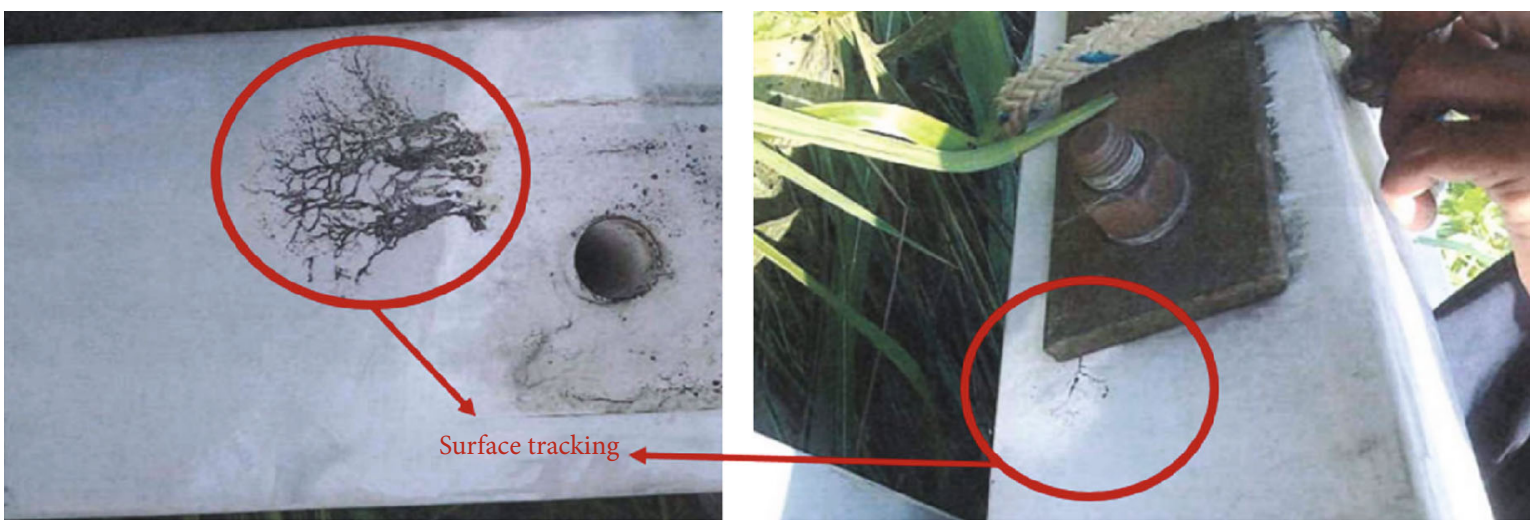

FIGURE 12: Surface tracking of PGFRP composite cross arm beams.

\section{Conclusions}

This manuscript presents a brief review on the potential of manufacturing cross arm components from natural fibre reinforced biopolymer composites. This green composite material has attracted the attention of many researchers and industrial sectors due to its excellent mechanical ability, and the material itself is a part of green technology. In the most recent research works reviewed, several natural fibres seem to be at par with synthetic fibre in terms of mechanical performance. In particular, flax and pineapple fibres have comparable tensile strength and stiffness values to glass fibre. Moreover, the physical, thermal, and mechanical properties of natural fibres can be enhanced either via physical or chemical treatments, which improve interfacial adhesion between fibre and its resin. Meanwhile, several biopolymers have the potential to replace the current synthetic polymers, such as PLA, PHA, and PHB. These biopolymers could be good candidates to be applied in structural applications especially as cross arm beams. Since the cross arms are made via pultrusion process, it is suggested that the natural fibre reinforced biopolymers could be conducted via the same process with the same configuration in order to develop green composite cross arms. In addition, it is useful to enhance their intrinsic properties and significantly improve the green composite cross arms developed from treated natural fibres. However, there are several properties that need to be identified and evaluated, such as creep, fatigue, and quasistatic mechanical performance, since green composite cross arms are new in this field. Hence, further exploration on more advanced processing techniques for natural fibre reinforced biopolymer composite cross arms is necessary to be conducted in order to replace the conventional cross arms in transmission towers.

\section{Data Availability}

The data used to support the findings of this study are included within the article.

\section{Conflicts of Interest}

The authors declare no conflict of interest in the article.

\section{Acknowledgments}

The authors are very thankful to the Department of Aerospace Engineering, Faculty of Engineering, Universiti Putra Malaysia (UPM), for providing space and facilities for this project. Moreover, all authors were also very thankful to Jabatan Perkhidmatan Awam (JPA) via Excellent Graduate Award Scholarship Award (PPC2019) and Kursi Rahmah Nawawi for providing financial aids to the first author to carry out this research project. This work was supported by the Fundamental Research Grant Scheme (FRGS/1/2019/TK05/02/11) with VOT No. 5540205 from Ministry of Higher Education, Malaysia, and partly from Universiti Kebangsaan Malaysia through a research grant, Dana Pecutan Penerbitan-LESTARI UKM [PP/LESTARI/2020] and XX-2018-008.

\section{References}

[1] M. Ramesh, K. Palanikumar, and K. H. Reddy, "Mechanical property evaluation of sisal-jute-glass fiber reinforced polyester composites," Composites Part B: Engineering, vol. 48, pp. 1-9, 2013.

[2] M. J. John and S. THOMAS, "Biofibres and biocomposites," Carbohydrate Polymers, vol. 71, no. 3, pp. 343-364, 2008.

[3] R. F. Aguilera, R. G. Eggert, G. Lagos Cruz-Coke, and J. E. Tilton, "Depletion and the future availability of petroleum resources," Energy Journal, vol. 30, no. 141, p. 174, 2009.

[4] H. Ritchie and M. Roser, $\mathrm{CO}_{2}$ and Greenhouse Gas Emissions, 2020, https://ourworldindata.org/co2-and-other-greenhousegas-emissions.

[5] M. Ramesh, K. Palanikumar, and K. H. Reddy, "Plant fibre based bio-composites: sustainable and renewable green materials," Renewable and Sustainable Energy Reviews, vol. 79, pp. 558-584, 2017.

[6] R. Drochytka, J. Zach, A. Korjenic, and J. Hroudová, "Improving the energy efficiency in buildings while reducing the waste using autoclaved aerated concrete made from power industry waste," Energy and Buildings, vol. 58, pp. 319-323, 2013.

[7] N. H. Wong, D. K. W. Cheong, H. Yan, J. Soh, C. L. Ong, and A. Sia, "The effects of rooftop garden on energy consumption of a commercial building in Singapore," Energy and Buildings, vol. 35, no. 4, pp. 353-364, 2003. 
[8] W. J. Stec, A. H. C. Van Paassen, and A. Maziarz, "Modelling the double skin façade with plants," Energy and Buildings, vol. 37, no. 5, pp. 419-427, 2005.

[9] M. Ottelé, K. Perini, A. L. A. Fraaij, E. M. Haas, and R. Raiteri, "Comparative life cycle analysis for green façades and living wall systems," Energy and Buildings, vol. 43, no. 12, pp. 3419-3429, 2011.

[10] G. Pérez, L. Rincón, A. Vila, J. M. González, and L. F. Cabeza, "Behaviour of green facades in Mediterranean Continental climate," Energy Conversion and Management, vol. 52, no. 4, pp. 1861-1867, 2011.

[11] J. Nickel and U. Riedel, "Activities in biocomposites," Materials Today, vol. 6, no. 4, pp. 44-48, 2003.

[12] M. R. M. Asyraf, M. R. Ishak, S. M. Sapuan, N. Yidris, and R. A. Ilyas, "Woods and composites cantilever beam: a comprehensive review of experimental and numerical creep methodologies," Journal of Materials Research and Technology, vol. 9, no. 3, pp. 6759-6776, 2020.

[13] D. C. T. Cardoso, K. A. Harries, and E. D. M. Batista, "Compressive strength equation for GFRP square tube columns," Composites Part B: Engineering, vol. 59, pp. 1-11, 2014.

[14] R. Rahman and S. Z. F. S. Putra, "Tensile properties of natural and synthetic fiber-reinforced polymer composites," in Mechanical and Physical Testing of Biocomposites, FibreReinforced Composites and Hybrid Composites, M. Thariq, N. Saba, and M. Jawaid, Eds., pp. 81-102, Woodhead Publishing Series, 2019.

[15] A. N. Johari, M. R. Ishak, Z. Leman, M. Z. M. Yusoff, and M. R. M. Asyraf, "Creep behaviour monitoring of short-term duration for fiber-glass reinforced composite cross-arms with unsaturated polyester resin samples using conventional analysis," Journal of Mechanical Engineering and Sciences, vol. 14, no. 3, 2020.

[16] A. N. Johari, M. R. Ishak, Z. Leman et al., "Fabrication and cut-in speed enhancement of savonius vertical axis wind turbine (SVAWT) with hinged blade using fiberglass composites," in Seminar Enau Kebangsaan, pp. 978-983, Institute of Tropical Forestry and Forest Products (INTROP), Universiti Putra Malaysia, Bahau, Negeri Sembilan, Malaysia, 2019.

[17] I. M. Rawi, M. S. A. Rahman, M. Z. A. Ab Kadir, and M. Izadi, "Wood and fiberglass crossarm performance against lightning strikes on transmission towers," in International Conference on Power Systems Transient (IPST), pp. 1-6, Sungkyunkwan University, Seoul, Republic of Korea, 2017.

[18] A. N. Johari, M. R. Ishak, Z. Leman, M. Z. M. Yusoff, and M. R. M. Asyraf, "Influence of $\mathrm{CaCO} 3$ in pultruded glass fibre/unsaturated polyester composite on flexural creep behaviour using conventional and TTSP methods," Polimery, vol. 65, no. 10, pp. 46-54, 2020.

[19] A. Alhayek, A. Syamsir, V. Anggraini, Z. C. Muda, and N. M. Nor, "Numerical modelling of glass fiber reinforced polymer (GFRP) cross arm," International Journal of Recent Technology and Engineering, vol. 8, no. 4, pp. 6484-6489, 2019.

[20] R. A. Ilyas and S. M. Sapuan, "Biopolymers and biocomposites: chemistry and technology," Current Analytical Chemistry, vol. 16, no. 5, pp. 500-503, 2020.

[21] R. A. Ilyas, S. M. Sapuan, A. Atiqah et al., "Sugar palm ( Arenga pinnata [ Wurmb .] Merr ) starch films containing sugar palm nanofibrillated cellulose as reinforcement: Water barrier properties," Polymer Composites, vol. 41, no. 2, pp. 459467, 2020.
[22] R. A. Ilyas, S. M. Sapuan, M. N. F. Norrrahim et al., "Nanocellulose/starch biopolymer nanocomposites: Processing, manufacturing, and applications," in Advanced Processing, Properties, and Applications of Starch and Other Bio-Based Polymers, F. M. Al-Oqla and S. M. Sapuan, Eds., pp. 65-88, Elsevier Inc., Amsterdam, Netherland, 2020.

[23] M. L. Sanyang, S. M. Sapuan, M. Jawaid, M. R. Ishak, and J. Sahari, "Recent developments in sugar palm (Arenga pinnata) based biocomposites and their potential industrial applications: a review," Renewable and Sustainable Energy Reviews, vol. 54, pp. 533-549, 2016.

[24] E. Zini and M. Scandola, "Green composites: an overview," Polymer Composites, vol. 32, no. 12, pp. 1905-1915, 2011.

[25] F. P. La Mantia and M. Morreale, "Green composites: a brief review," Composites Part A: Applied Science and Manufacturing, vol. 42, no. 6, pp. 579-588, 2011.

[26] G. Koronis, A. Silva, and M. Fontul, "Green composites: a review of adequate materials for automotive applications," Composites Part B: Engineering, vol. 44, no. 1, pp. 120-127, 2013.

[27] X. Cao, Y. Chen, P. R. Chang, M. Stumborg, and M. A. Huneault, "Green composites reinforced with hemp nanocrystals in plasticized starch," Journal of Applied Polymer Science, vol. 109, no. 6, pp. 3804-3810, 2008.

[28] R. Ilyas, S. M. Sapuan, M. S. N. Atikah et al., "Effect of hydrolysis time on the morphological, physical, chemical, and thermal behavior of sugar palm nanocrystalline cellulose (Arenga pinnata (Wurmb.) Merr)," Textile Research Journal, 2020.

[29] M. R. M. Asyraf, M. Rafidah, M. R. Ishak et al., "Integration of TRIZ, morphological chart and ANP method for development of FRP composite portable fire extinguisher," Polymer Composites, vol. 41, no. 7, pp. 2917-2932, 2020.

[30] R. A. Ilyas, S. M. Sapuan, M. R. M. Asyraf et al., "Introduction to biofiller reinforced degradable polymer composites," in Biofiller Reinforced Biodegradable Polymer Composites, S. M. Sapuan, R. Jumaidin, and I. Hanafi, Eds., CRC press, Boca Raton, USA, 2020.

[31] R. Siakeng, M. Jawaid, H. Ariffin, and S. M. Sapuan, "Mechanical, Dynamic, and Thermomechanical Properties of Coir / Pineapple Leaf Fiber Reinforced Polylactic Acid Hybrid Biocomposites," Polymer Composites, vol. 40, no. 5, pp. 1-12, 2018.

[32] M. R. M. Asyraf, M. R. Ishak, S. M. Sapuan et al., "Creep test rig for cantilever beam: fundamentals, prospects and present views," Journal of Mechanical Engineering and Sciences, vol. 14, no. 2, pp. 6869-6887, 2020.

[33] M. R. M. Asyraf, M. R. Ishak, M. R. Razman, and M. Chandrasekar, "Fundamentals of creep, testing methods and development of test rig for the full-scale crossarm: a review," Jurnal Teknologi, vol. 81, no. 4, pp. 155-164, 2019.

[34] P. R. Vieira, E. M. L. Carvalho, J. D. Vieira, and R. D. Toledo Filho, "Experimental fatigue behavior of pultruded glass fibre reinforced polymer composite materials," Composites Part B: Engineering, vol. 146, pp. 69-75, 2018.

[35] C. N. A. Jaafar, M. A. M. Rizal, and I. Zainol, "Effect of kenaf alkalization treatment on morphological and mechanical properties of epoxy/silica/kenaf composite," International Journal of Engineering \& Technology, vol. 7, no. 4.35, pp. 258-263, 2018.

[36] K. Goda and Y. Cao, "Research and development of fully green composites reinforced with natural fibers," Journal of 
Solid Mechanics and Materials Engineering, vol. 1, no. 9, pp. 1073-1084, 2007.

[37] M. L. Sanyang, S. M. Sapuan, M. Jawaid, M. R. Ishak, and J. Sahari, "Effect of sugar palm-derived cellulose reinforcement on the mechanical and water barrier properties of sugar palm starch biocomposite films," BioResources, vol. 11, no. 2, pp. 4134-4145, 2016.

[38] R. A. Ilyas, M. S. Sapuan, M. N. Norizan et al., "Macro to nanoscale natural fiber composites for automotive components: research, development, and application," in Biocomposite and Synthetic Composites for Automotive Applications, M. S. Sapuan and R. A. Ilyas, Eds., Woodhead Publishing Series, Amsterdam, Netherland, 2020.

[39] L. Yan, N. Chouw, and X. Yuan, "Improving the mechanical properties of natural fibre fabric reinforced epoxy composites by alkali treatment," Journal of Reinforced Plastics and Composites, vol. 31, no. 6, pp. 425-437, 2012.

[40] A. K. Bledzki and J. Gassan, "Composites reinforced with cellulose based fibres," Progress in Polymer Science, vol. 24, no. 2, pp. 221-274, 1999.

[41] J. George, M. S. Sreekala, and S. Thomas, "A review on interface modification and characterization of natural fiber reinforced plastic composites," Polymer Engineering \& Science, vol. 41, no. 9, pp. 1471-1485, 2001.

[42] M. Karus, "Market and economy of natural and wood fibre reinforced plastics," Proc of SusCompNet 9: Sustainability and biocomposites-A one day seminar, Ris $\varnothing$ National Laboratory, Denmark, 2005.

[43] O. Faruk, A. K. Bledzki, H. P. Fink, and M. Sain, "Progress report on natural fiber reinforced composites," Macromolecular Materials and Engineering, vol. 299, no. 1, pp. 9-26, 2014.

[44] M. L. Sanyang, R. A. Ilyas, S. M. Sapuan, and R. Jumaidin, "Sugar palm starch-based composites for packaging applications," in Bionanocomposites for Packaging Applications, pp. 125-147, Springer, 2017.

[45] M. R. Ishak, S. M. Sapuan, Z. Leman, M. Z. A. Rahman, U. M. K. Anwar, and J. P. Siregar, "Sugar palm (Arenga pinnata): its fibres, polymers and composites," Carbohydrate Polymers, vol. 91, no. 2, pp. 699-710, 2013.

[46] A. Bismarck, S. Mishra, and T. Lampke, "Plant fibers as reinforcement for green composites," in Natural Fibers, Biopolymers, and Biocomposites, pp. 52-128, CRC Press, 2005.

[47] M. R. Ketabchi, M. E. Hoque, and M. Khalid Siddiqui, "Critical concerns on manufacturing processes of natural fibre reinforced polymer composites," in Manufacturing of Natural Fibre Reinforced Polymer Composites, S. M. Sapuan, M. Jawaid, N. Yusoff, and M. E. Hoque, Eds., pp. 125138, Springer International Publishing, Cham, Switzerland, 2015.

[48] R. A. Butler, "Malaysia has the world's highest deforestation rate," https://news.mongabay.com/wildtech/2013/11/ malaysia-has-the-worlds-highest-deforestation-rate-revealsgoogle-forest-map/.

[49] M. Ramesh, "Flax (Linum usitatissimum L.) fibre reinforced polymer composite materials: a review on preparation, properties and prospects," Progress in Materials Science, vol. 102, pp. 109-166, 2019.

[50] M. Ramesh, "Kenaf (Hibiscus cannabinus L.) fibre based biomaterials: a review on processing and properties," Progress in Materials Science, vol. 78-79, pp. 1-92, 2016.
[51] R. Belhassen, S. Boufi, F. Vilaseca et al., "Biocomposites based on Alfa fibers and starch-based biopolymer," Polymers for Advanced Technologies, vol. 20, no. 12, pp. 1068-1075, 2009.

[52] M. Ramesh, C. Deepa, L. R. Kumar, M. R. Sanjay, and S. Siengchin, "Life-cycle and environmental impact assessments on processing of plant fibres and its bio-composites: a critical review," Journal of Industrial Textiles, 2020.

[53] A. K. Mohanty, M. Misra, and L. T. Drzal, "Sustainable biocomposites from renewable resources: opportunities and challenges in the green materials world," Journal of Polymers and the Environment, vol. 10, no. 1/2, pp. 19-26, 2002.

[54] W. Lu, H. Lin, D. Wu, and G. Chen, "Unsaturated polyester resin/graphite nanosheet conducting composites with a low percolation threshold," Polymer, vol. 47, no. 12, pp. 44404444, 2006.

[55] D. Zindani, S. Kumar, S. R. Maity, and S. Bhowmik, "Mechanical characterization of bio-epoxy green composites derived from sodium bicarbonate treated Punica granatum short fiber agro-waste," Journal of Polymers and the Environment, 2020.

[56] P. A. Fowler, J. M. Hughes, and R. M. Elias, "Biocomposites: technology, environmental credentials and market forces," Journal of the Science of Food and Agriculture, vol. 86, no. 12, pp. 1781-1789, 2006.

[57] D. Francia, G. Caligiana, A. Liverani, L. Frizziero, and G. Donnici, "PrinterCAD: a QFD and TRIZ integrated design solution for large size open moulding manufacturing," International Journal on Interactive Design and Manufacturing, vol. 12, no. 1, pp. 81-94, 2018.

[58] R. Crutchlow, "Changing from open to closed moulding," Reinforced Plastics, vol. 48, no. 8, pp. 40-41, 2004.

[59] N. S. B. Yusof, S. M. Sapuan, M. T. H. Sultan, and M. Jawaid, "Manufacturing process selection of "green" oil palm natural fiber reinforced polyurethane composites using hybrid TEA criteria requirement and AHP method for automotive crash box," Journal of Renewable Materials, vol. 8, no. 6, pp. 647-660, 2020.

[60] M. Jacob, S. Joseph, L. A. Pothan, and S. Thomas, "A study of advances in characterization of interfaces and fiber surfaces in lignocellulosic fiber-reinforced composites," Composite Interfaces, vol. 12, no. 1-2, pp. 95-124, 2005.

[61] P. V. Joseph, K. Joseph, and S. Thomas, "Short sisal fiber reinforced polypropylene composites: the role of interface modification on ultimate properties," Composite Interfaces, vol. 9, no. 2, pp. 171-205, 2002.

[62] A. M. Fairuz, S. M. Sapuan, E. S. Zainudin, and C. N. A. Jaafar, "Polymer composite manufacturing using a pultrusion process: a review," American Journal of Applied Sciences, vol. 11, no. 10, pp. 1798-1810, 2014.

[63] S. M. Moschiar, M. M. Reboredo, J. M. Kenny, and A. Vázquez, "Analysis of pultrusion processing of composites of unsaturated polyester resin with glass fibers," Polymer Composites, vol. 17, no. 3, pp. 478-485, 1996.

[64] H. Y. Yeh and S. C. Yang, "Building of a composite transmission tower," Journal of Reinforced Plastics and Composites, vol. 16, no. 5, pp. 414-424, 1997.

[65] I. Baran, C. C. Tutum, M. W. Nielsen, and J. H. Hattel, "Process induced residual stresses and distortions in pultrusion," Composites Part B: Engineering, vol. 51, pp. 148-161, 2013.

[66] W. Huchang and W. Xueming, "Material selection for transmission tower made of fiber reinforced plastics," Electrical Power Construction, vol. 32, no. 2, pp. 1-5, 2011. 
[67] S. Ibrahim, D. Polyzois, and S. K. Hassan, "Development of glass fiber reinforced plastic poles for transmission and distribution lines," Canadian Journal of Civil Engineering, vol. 27, no. 5, pp. 850-858, 2000.

[68] E. V. Morozov, "The effect of filament-winding mosaic patterns on the strength of thin-walled composite shells," Composite Structures, vol. 76, no. 1-2, pp. 123-129, 2006.

[69] V. Birman and G. A. Kardomateas, "Review of current trends in research and applications of sandwich structures," Composites Part B: Engineering, vol. 142, pp. 221-240, 2018.

[70] SAE International, Composite Materials Handbook, Volume 6. Structural Sandwich Composites, SAE International, 2013.

[71] R. Roy, S. J. Park, J. H. Kweon, and J. H. Choi, "Characterization of Nomex honeycomb core constituent material mechanical properties," Composite Structures, vol. 117, no. 1, pp. 255-266, 2014.

[72] Y. Fu and P. Sadeghian, "Flexural and shear characteristics of bio-based sandwich beams made of hollow and foam-filled paper honeycomb cores and flax fiber composite skins," Thin-Walled Structures, vol. 153, article 106834, 2020.

[73] A. Önder and M. Robinson, "Investigating the feasibility of a new testing method for GFRP/polymer foam sandwich composites used in railway passenger vehicles," Composite Structures, vol. 233, article 111576, 2020.

[74] F. E. Sezgin, M. Tanoğlu, O. Ö. Eğilmez, and C. Dönmez, "Mechanical behavior of polypropylene-based honeycombcore composite sandwich structures," Journal of Reinforced Plastics and Composites, vol. 29, no. 10, pp. 1569-1579, 2010.

[75] S. A. H. Roslan, M. Z. Hassan, Z. A. Rasid et al., "Mechanical properties of bamboo reinforced epoxy sandwich structure composites," International Journal of Automotive and Mechanical Engineering, vol. 12, pp. 2882-2892, 2015.

[76] A. Niknejad, M. M. Abedi, G. H. Liaghat, and M. Zamani Nejad, "Prediction of the mean folding force during the axial compression in foam-filled grooved tubes by theoretical analysis," Materials and Design, vol. 37, pp. 144-151, 2012.

[77] J. Xiang and J. Du, "Energy absorption characteristics of bioinspired honeycomb structure under axial impact loading," Materials Science and Engineering A, vol. 696, pp. 283-289, 2017.

[78] M. Nouri Damghani and A. Mohammadzadeh Gonabadi, "Analytical and numerical study of foam-filled corrugated core sandwich panels under low velocity impact," Mechanics, Materials Science \& Engineering, vol. 7, pp. 176-200, 2016.

[79] S. Shi, Z. Sun, X. Hu, and H. Chen, "Flexural strength and energy absorption of carbon-fiber-aluminum-honeycomb composite sandwich reinforced by aluminum grid," ThinWalled Structures, vol. 84, pp. 416-422, 2014.

[80] L. Tian, H. Pan, R. Ma, L. Zhang, and Z. Liu, "Full-scale test and numerical failure analysis of a latticed steel tubular transmission tower," Engineering Structures, vol. 208, article 109919, 2020.

[81] H. Yin, G. Wen, S. Hou, and K. Chen, "Crushing analysis and multiobjective crashworthiness optimization of honeycombfilled single and bitubular polygonal tubes," Materials and Design, vol. 32, no. 8-9, pp. 4449-4460, 2011.

[82] J. Simpson and Z. Kazanc1, "Crushing investigation of crash boxes filled with honeycomb and re-entrant (auxetic) lattices," Thin-Walled Structures, vol. 150, article 106676, 2020.
[83] Z. Wang and J. Liu, "Numerical and theoretical analysis of honeycomb structure filled with circular aluminum tubes subjected to axial compression," Composites Part B: Engineering, vol. 165, pp. 626-635, 2019.

[84] Z. Wang, J. Liu, Z. Lu, and D. Hui, "Mechanical behavior of composited structure filled with tandem honeycombs," Composites Part B: Engineering, vol. 114, pp. 128-138, 2017.

[85] D. Mohamad, A. Syamsir, Z. Itam et al., "Numerical simulation on the statics deformation study of composite cross arms of different materials and configurations," IOP Conference Series: Materials Science and Engineering, vol. 530, no. 1, 2019.

[86] D. Mohamad, A. Syamsir, S. Beddu et al., "Numerical study of composite fiberglass cross arms under statics loading and improvement with sleeve installation," IOP Conference Series: Materials Science and Engineering, vol. 530, article 012027, 2019.

[87] T. Jahangiri, Q. Wang, F. F. da Silva et al., "Fiber reinforced plastic (FRP) composite selection for the composite crossarm core," in Electrical Design of a $400 \mathrm{kV}$ Composite Tower, T. Jahangiri, Q. Wang, F. F. Silva, and C. L. Bak, Eds., pp. 1565, Springer, Cham, Switzerland, 2020.

[88] V. Peesapati, C. Zachariades, Q. Li et al., "3D electric field computation of a composite cross-arm," in 2012 IEEE International Symposium on Electrical Insulation, pp. 464-468, San Juan, PR, USA, June 2012.

[89] I. M. Rawi and M. Z. A. Ab Kadir, "Investigation on the $132 \mathrm{kV}$ overhead lines lightning-related flashovers in Malaysia," in 2015 International Symposium on Lightning Protection (XIII SIPDA), pp. 239-243, Balneario Camboriu, Brazil, September 2015.

[90] R. Burgueño, M. J. Quagliata, A. K. Mohanty, G. Mehta, L. T. Drzal, and M. Misra, "Hybrid biofiber-based composites for structural cellular plates," Composites Part A: Applied Science and Manufacturing, vol. 36, no. 5, pp. 581-593, 2005.

[91] P. Wambua, J. Ivens, and I. Verpoest, "Natural fibres: can they replace glass in fibre reinforced plastics?," Composites Science and Technology, vol. 63, no. 9, pp. 1259-1264, 2003.

[92] S. Beddu, A. Syamsir, Z. A. M. Ishak, Z. M. Yusof, N. S. Hudi, and S. Nabihah, "Creep behavior of glass fibre reinforced polymer structures in crossarms transmission line towers," AIP Conference Proceedings, vol. 2031, article 020039, 2018.

[93] H. K. Sharaf, M. R. Ishak, S. M. Sapuan, N. Yidris, and A. Fattahi, "Experimental and numerical investigation of the mechanical behavior of full-scale wooden cross arm in the transmission towers in terms of load-deflection test," Journal of Materials Research and Technology, vol. 9, no. 4, pp. 7937-7946, 2020.

[94] M. R. M. Asyraf, M. R. Ishak, S. M. Sapuan, and N. Yidris, "Conceptual design of creep testing rig for full-scale cross arm using TRIZ-morphological chart-analytic network process technique," Journal of Materials Research and Technology, vol. 8, no. 6, pp. 5647-5658, 2019.

[95] M. R. M. Asyraf, M. R. Ishak, S. M. Sapuan, and N. Yidris, "Conceptual design of multi-operation outdoor flexural creep test rig using hybrid concurrent engineering approach," Journal of Materials Research and Technology, vol. 9, no. 2, pp. 2357-2368, 2020.

[96] M. R. M. Asyraf, M. R. Ishak, S. M. Sapuan et al., "Evaluation of design and simulation of creep test rig for full-scale crossarm structure," Advances in Civil Engineering, vol. 2020, Article ID 6980918, 10 pages, 2020. 
[97] H. K. Sharaf, M. R. Ishak, S. M. Sapuan, and N. Yidris, "Conceptual design of the cross-arm for the application in the transmission towers by using TRIZ-morphological chartANP methods," Journal of Materials Research and Technology, vol. 9, no. 4, pp. 9182-9188, 2020.

[98] S. Zainuddin, A. Mascunra Amir, Y. R. Kibi, M. Khairil, S. Zarina Syed Zakaria, and M. Rizal Razman, "Social engineering model of natural resources management of Palu City," Journal of Engineering and Applied Sciences, vol. 14, no. 1, pp. 275-279, 2019.

[99] S. S. S. Ali, M. R. Razman, and A. Awang, "The nexus of population, GDP growth, electricity generation, electricity consumption and carbon emissions output in Malaysia," International Journal of Energy Economics and Policy, vol. 10, no. 3, pp. 84-89, 2020.

[100] S. M. Sapuan, K. R. Purushothman, M. L. Sanyang, and M. R. Mansor, "Design and fabrication of kenaf fibre reinforced polymer composites for portable laptop table," in Lignocellulosic Composite Materials, S. Kalia, Ed., pp. 323-356, Springer Nature, Gewerbestrasse, Switzerland, 2018.

[101] M. R. Mansor, S. M. Sapuan, A. Hambali, E. S. Zainudin, and A. A. Nuraini, "Conceptual design of kenaf polymer composites automotive spoiler using TRIZ and Morphology chart methods," Applied Mechanics and Materials, vol. 761, pp. 63-67, 2015.

[102] N. Mazani, S. M. Sapuan, M. L. Sanyang, A. Atiqah, and R. A. Ilyas, "Design and fabrication of a shoe shelf from kenaf fiber reinforced unsaturated polyester composites," in Lignocellulose for Future Bioeconomy, H. Ariffin, S. M. Sapuan, and M. A. Hassan, Eds., pp. 315-332, Elsevier Inc., Amsterdam, Netherland, 2019.

[103] S. M. Sapuan, Tropical Natural Fibre Composites: Properties, Manufacture and Applications. Springer Science+Business Media Singapore, Singapore, 2014.

[104] S. M. Sapuan, “A conceptual design of the concurrent engineering design system for polymeric-based composite automotive pedals," American Journal of Applied Sciences, vol. 2, no. 2, pp. 514-525, 2005.

[105] N. M. Ishak, D. Sivakumar, and M. R. Mansor, "The application of TRIZ on natural fibre metal laminate to reduce the weight of the car front hood," Journal of the Brazilian Society of Mechanical Sciences and Engineering, vol. 40, no. 2, pp. 1-12, 2018.

[106] M. A. Shaharuzaman, S. M. Sapuan, M. R. Mansor, and M. Y. M. Zuhri, "Conceptual design of natural fiber composites as a side-door impact beam using hybrid approach," Journal of Renewable Materials, vol. 8, no. 5, pp. 549-563, 2020.

[107] A. M. N. Azammi, S. M. Sapuan, M. R. Ishak, and M. T. H. Sultan, "Conceptual design of automobile engine rubber mounting composite using TRIZ-Morphological chartanalytic network process technique," Defence Technology, vol. 14, no. 4, pp. 268-277, 2018.

[108] R. A. Ilyas, S. M. Sapuan, R. Ibrahim et al., “Thermal, biodegradability and water barrier properties of bio-nanocomposites based on plasticised sugar palm starch and nanofibrillated celluloses from sugar palm fibres," Journal of Biobased Materials and Bioenergy, vol. 14, no. 2, pp. 234-248, 2020.

[109] T. Khan, M. T. B. Hameed Sultan, and A. H. Ariffin, "The challenges of natural fiber in manufacturing, material selection, and technology application: a review," Journal of Reinforced Plastics and Composites, vol. 37, no. 11, pp. 770-779, 2018.
[110] S. S. Bhagawan, D. K. Tripathy, and S. K. De, "Stress relaxation in short jute fiber-reinforced nitrile rubber composites," Journal of Applied Polymer Science, vol. 33, no. 5, pp. 16231639, 1987.

[111] K. N. Law, W. R. W. Daud, and A. Ghazali, "Morphological and chemical nature of fiber strands of oil palm emptyfruit-bunch (OPEFB)," BioResources, vol. 2, no. 3, pp. 351362, 2007.

[112] N. Amir, K. A. Z. Abidin, and F. B. M. Shiri, "Effects of fibre configuration on mechanical properties of banana fibre/PP/MAPP natural fibre reinforced polymer composite," Procedia Engineering, vol. 184, pp. 573-580, 2017.

[113] I. S. M. A. Tawakkal, R. A. Talib, K. Abdan, and C. N. Ling, "Mechanical and physical properties of kenaf-derived cellulose (KDC)-filled polylactic acid (PLA) composites," BioResources, vol. 7, no. 2, pp. 1643-1655, 2012.

[114] D. Bachtiar, M. S. Salit, E. Zainudin, K. Abdan, and K. Z. H. M. Dahlan, "Effects of alkaline treatment and a compatibilizing agent on tensile properties of sugar palm fibrereinforced high impact polystyrene composites," BioResources, vol. 6, no. 4, pp. 4815-4823, 2011.

[115] M. H. Mustafa and B. Dauda, "Unsaturated Polyester Resin Reinforced With Chemically Modified Natural Fibre $\backslash n$," IOSR Journal of Polymer and Textile Engineering (IOSRJPTE), vol. 1, no. 4, pp. 31-38, 2014.

[116] M. Hosur, H. Maroju, and S. Jeelani, "Comparison of effects of alkali treatment on flax fibre reinforced polyester and polyester-biopolymer blend resins," Polymers and Polymer Composites, vol. 23, no. 4, pp. 229-242, 2018.

[117] C. Y. Lai, S. M. Sapuan, M. Ahmad, N. Yahya, and K. Z. H. M. Dahlan, "Mechanical and electrical properties of coconut coir fiber-reinforced polypropylene composites," Polymer-Plastics Technology and Engineering, vol. 44, no. 4, pp. 619-632, 2005.

[118] M. S. Huda, L. T. Drzal, A. K. Mohanty, and M. Misra, "Effect of chemical modifications of the pineapple leaf fiber surfaces on the interfacial and mechanical properties of laminated biocomposites," Composite Interfaces, vol. 15, no. 2-3, pp. 169-191, 2008.

[119] K. Ryder, M. A. Ali, A. Carne, and J. Billakanti, “The potential use of dairy by-products for the production of nonfood biomaterials," Critical Reviews in Environmental Science and Technology, vol. 47, no. 8, pp. 621-642, 2017.

[120] A. K. Mohanty, M. Misra, and G. Hinrichsen, "Biofibres, biodegradable polymers and biocomposites: an overview," Macromolecular Materials and Engineering, vol. 276-277, no. 1, pp. 1-24, 2000.

[121] A. Al Mahmood, "Characterization of glass fibre reinforced polymer composite prepared by hand layup method," American Journal of Bioscience and Bioengineering, vol. 5, no. 1, p. 8, 2017.

[122] A. Gregorova, R. Wimmer, M. Hrabalova, M. Koller, T. Ters, and N. Mundigler, "Effect of surface modification of beech wood flour on mechanical and thermal properties of poly (3-hydroxybutyrate)/wood flour composites," Holzforschung, vol. 63, no. 5, pp. 565-570, 2009. 